\title{
Pendidikan Agama Sebagai Branding di Media Sosial
}

\author{
Arif Al Anang ${ }^{1}$, Ahmad Husein ${ }^{2}$, Abdul Rasyad ${ }^{3}$ \\ ${ }^{1}$ Universitas Gadjah Mada \\ radenarifmasduki@gmail.com \\ ${ }^{2}$ Universitas Islam Negeri Sunan Kalijaga \\ lubis2925@gmail.com \\ ${ }^{3}$ Universitas Hamzanwadi \\ rasyad.iis@hamzanwadi.ac.id
}

\begin{abstract}
Abstrak
Pendidikan agama adalah salah satu kebutuhan spiritual masyarakat. Di era kemajuan teknologi dan sains yang begitu pesat. Pendidikan agama tidak bisa ditinggalkan masyarakat karena dengan agama masyarakat akan menjadi bermoral dalam hidup. Kemajuan suatu bangsa dan negara dilihat dari sistem pendidikan, kemajuan pendidikan Barat sudah sangat jauh meninggalkan pendidikan keagamaan di Indonesia, para modernis membuat suatu pendidikan model baru mendapat sambutan positif. Modernisasi pendidikan Islam menjadi Branding di tengah kalangan masyarakat Indonesia, Branding yang ditawarkan adalah program unggulan seperti tahfizh al-Qur'an yang dipromosikan di media sosial (facebook).
\end{abstract}

Kata Kunci: Pendidikan, Branding, Media Sosial, Program Tahfizh

\begin{abstract}
Religious education is one of the spiritual needs of society. In an era of rapid technological and scientific advances. Religious education cannot be abandoned by society because with religion the community will become moral in life. the progress of a nation and the State seen from the education system, the progress of western education has very far left religious education in Indonesia, the modernists made a new model of education received a positive response. Modernization of Islamic education has become branding among Indonesians. The branding that is offered is a superior program such as tahfizh al-Qur'an which is promoted on social media (facebook).
\end{abstract}

Keywords: Education, Branding, Social Media, Tahfizh Program

\section{Pendahuluan}

Sebuah inovasi pembaruan dalam dunia pendidikan Islam yang ditawarkan Ainur Rafiq dengan sebuah paradigma integrasi sangat cocok sekali untuk diterapkan di era sekarang. Bagi Ainur Rofiq Dawam, setidaknya pilar pendidikan Islam mengandung empat sumber khazanah intelektual yang harus dikembangkan. Keempat sumber khazanah intelektual tersebut yaitu wahyu transenden (al-Qur'an dan Hadis), ayat-ayat 
kauniyah (fenomena alam semesta), ayat-ayat ijtima'iyyah (interaksi sosial), dan ayatayat wujdaniyah (nurani pribadi) (Suyatno, 2013: 355-377).

Keempat sumber khazanah intelektual tersebut masing-masing memiliki wilayah kerja sendiri-sendiri, misalnya wahyu Tuhan memiliki wilayah yang jelas dan pasti yaitu berupa teks-teks suci agama yang terkandung dalam al-Qur'an dan Hadis.Khazanah intelektual Islam dari sumber yang pertama ini merupakan sumber primordial dalam panduan dalam beragama, sehingga dari sumber ini memunculkan berbagai disiplin ilmu yang berkaitan erat dengan tuntutan hdup yang lebih saleh (way of life).Seperti ilmu tauhid atau ilmu akidah dan ilmu hukum atau syari'ah.Meskipun kedua disiplin ilmu ini memiliki objek formal yang berbeda, namun dilihat dari objek materinya adalah sama, yakni teks-teks dalam al-Qur'an atau sunnah. Entitas kedua sumber di atas keberadaanya saling melengkapi antara satu dengan yang lain. Tak jarang suatu permasalahan yang mana permasalahan tersebut butuh penjelasan secara eksplisit namun justru dalam sumber primer pada khazanah pertama ini tidak ditemukan sehingga harus merujuk pada Hadis, dan sebaliknya.

Wilayah khazanah intelektual yang kedua, yaitu yang bersumber dari ayat-ayat kauniyah (fenomena alam semesta), dalam khazanah intelektual ini berbeda dengan wilayah khazanah intelektual yang bersumber dari wahyu. Wilayah khazanah intelektual ini memberikan perhatian yang lebih besar terhadap fenomena alam yang belakangan memunculkan berbagai disiplin ilmu. Seperti halnya fenomena bencana alam yang membuat manusia berfikir untuk mencari solusinyanya. Dalam wilayah ini ilmu yang paling utama dihasilkan dari khazanah intelektual ini yaitu, filsafat, Sains, dan Teknologi. Namun keberadaan disiplin ilmu-ilmu di atas masih jarang sekali mendapatkan porsi cukup untuk diajarkan di lembaga-lembaga pendidikan Islam, kecuali hanya beberapa kesempatan saja.

Wilayah khazanah ketiga yaitu khazanah intelektual yang bersumber dari ayatayat ijtima'iyyah (interaksi sosial). Dalam khazanah intelektual ini sangat berbedacara kinerjanya dengan dua wilayah khazanah intelektual sebelumnya. Wilayah khazanah ini berupaya melihat lebih mendalam pada cara dan proses interaksi di antara sesama manusia (ta'ayusy baina al-Nas). Dalam wilayah khazanah intelektual ini telah berhasil memunculkan pelbagaidisiplin ilmu pngetahuan, ilmu psikologi jiwa, ilmu dalam beretorika, dan yang paling utama adalah ilmu politik dan ekonomi. Wilayah khazanah 
kedua dan yang ketiga hampir memiliki kesamaan dalam jalur kinerjanya yaitu samasama dalam ruang lingkup komunal, namun secara substansi dalam khazanah ini terdapat kesenjangan kinerja dengan sebelumnya.

Wilayah khazanah keempat yaitu khazanah intelektual yang bersumber pada ayatayat wujdaniyah (pengalaman atau nurani pribadi). Pada wilayah keempat ini lebih menekankan pada pengalaman-pengalaman dan nurani seseorang yang tidak sama dan tidak mudah ditiru oleh orang lain. Dalam wilayah ini hampir materi yang terkandung di dalamnya murni bersumber dari pengalaman seorang salik (seorang yang sedang menuju Tuhan) dan jarang sekali muatan-muatannya bisa dinalar dengan ukuran empiris. Wilayah intelektual ini memiliki peran andil yang cukup besar dalam kekayaan khazanah intelektual muslim, terutama pada paska era tabi'in (Isa, 2005: 9). Dalam kajian ini menawarkan sebuah solusi yang seakan-akan jawabannya tidak tertulis dalam buku dan masih bersifat mistis dari hati seorang salik. Kemudian seiring maraknya peminat kajian ini, belakangan wilayah di atas sering diistilahkan dengan ilmu tasawuf (mistis).

Di Indonesia lembaga pendidikan yang berkembang di masyarakat saat ini terdapat dua arus besar, yaitu sebuah lembaga pendidikan yang berada dibawah naungan kementrian Pendidikan dan Kebudayaan, dan yang kedua berada di bawah Kementerian Agama.Namun tak sedikit juga, terdapat lembaga-lembaga pendidikan yang tidak berafiliasi pada kedua kementerian di atas. Sebab bagi mereka terdapat ketidak cocokan dalam pembentukan kurikulum yang akan diberikan pada peserta didik. Sebut saja lembaga Islam tradisional (pesantren) sebagian di Indonesia memiliki kurikulum dan cara pengajaran yang berbeda dengan kebanyakan yang diajarkan pada sekolah-sekolah pada umumnya. Sistem yang diajarkan di pesantren ini murni hanya mengajarkan ilmu-ilmu agama yang berorentasi mendekatkan diri kepada sang Maha Pencipta.

Bagi sebagian kelompok masyarakat masih memegang doktrin lama yaitu bahwa dalam dunia pendidikan masih terdapat kooptasi antara pedidikan umum dan agama. Konsep pendidikan umum masih dipandang sebagai benalu bagi sebagian penuntut ilmu. Sebagian orang berkeyakinan bahwa mencari ilmu semata-mata karena Allah semata. Tidak sepatuhnya bagi para penuntut ilmu mempunyai cita-cita mencari ilmu setinggi langit hanya karena untuk mendapatkan sebuah profesi yang lebih mapan. Cara pandang semacam ini masih dipertahankan bagi sebagian kelompok masyarakat hingga saat ini, terkhusus di kalangan para priyai yang hidup di lingkungan pesantren. Sebagian dari 
mereka menganggap bahwa ilmu umum merupakan peninggalan semata dari pemerintahan Kolonial yang bersifat bid'ah dan haram, sehingga mereka melarang keras untuk mempelajarinya. Sehingga terjadilah dikotomi yang sangat ketat antara ilmu-ilmu umum dengan agama pada sistem pendidikan Islam tradisional (pesantren).

Sistem demikian ini tentu akan membuat anak didik menjadi gagap terhadap perkembangan teknologi. Kondisi demikian ini menyebabkan sistem pendidikan Islam tradisional mengalami ketinggalan terhadap kemajuan IPTEK. Sebab, menganut sistem demikian ini porsi pengajaran materi umum yang diberikan pada anak didik sangat kurang atau bahkan tidak ada sama sekali. Hal itu menyebabkan usaha mencetak para out put sekolah-sekolah berbasis Islam tradisonal yang sesuai harapan mayoritas muslim modern sekarang sangat sedikit sekali. Sehingga dari sini sangat butuh sekali untuk melakukan sebuah pembaruan (tajdid) dalam sistem dunia pendidikan Islam tradisional.

Sementara pendidikan gaya baru yang di tawarkan pesantren tradisional kurang diminati masyarakat muslim pada era ini, perpindahan kepercayaan orang tua kepada pendidikan tradisonal menurun misalnya di beberapa pesantren Mandailing Natal jumlah anak didik mereka tahun pertahun menurun disebabkan gaya pendidikan yang ditawarkan pesantren tidak berubah (monoton) dan kenakalan anak pesantren yang kurang terawasi menjaadi image buruk untuk pesantern juga mendapat stigma negatif di dalam masyarakat dan anggapan masyarakat kepada pesantren apalagi di kalangan masyarakat menengah ke atas tidak berminat lagi untuk melanjutkan pendidikan anak mereka di pesantren. Masyarakat berpikir bahwa kualitas pendidikan modern lebih bagus dari pesantren tradisional kerena pengaruh media sosial yang begitu marak melihat iklan-iklan dan prestasi-prestasi yang diposting pihak pesantren di facebook sehingga menumbuhkan pikiran yang baik dalam pikiran masyarakat.

Penelitian tentang pendidikan Islam sudah banyak dilakukan, di antaranya penelitian tentang "Strategi Lembaga Pendidikan Islam Dalam Membangun Branding Image" (Mundiri, 2016). Penelitian tentang “Strategi Pembelajaran Tahfidz Al-Qur'an di Lembaga Pendidikan" (Hidayah, 2016). Penelitian tentang "Strategi Pengelolaan Media Sosial dalam Pengembangan Dakwah di Majelis Taklim Dzikir dan Sholawat As-Shofa Banjarmasin" (Lukmana, 2019). Penelitian tentang "Penguatan Dakwah Virtual sebagai Upaya Memakmurkan Masjid Berbasis kegiatan Remaja Masjid" (Hariyati, dan Wahdiyati, 2019). Secara khusus penelitian tersebut tidak membahas tahfizh al-Qur'an 
sebagai brand dalam pengelolaan pendidikan Islam. Oleh karena itu urgensi penelitian ini hendak menjelaskan posisi strategis branding pendidikan agama di media sosial menggunakan facebook.

\section{Metode Penelitian}

Penelitian ini menggunakan penelitian kepustakaan dengan teknik analisis deskriptif analitis (Zeid, 2014), sehingga pemetaan perkembangan pendidikan agama Islam di Pondok Pesantren lebih jelas menunjukkan bagaimana branding itu berkembang dan menjadi bagian dari strategi pendidikan Islam sekarang ini. Data didapatkan dari sumber artikel dan jurnal, buku, dan berita yang ada di media massa. Penelitian ini menggunakan metode analisis deskriptif untuk menganalisis data (Sugiyono, 2014). Data ditinjau dan diselidiki dalam tiga tahap; umum, eksploratif, dan fokus belajar. Ini merupakan bahan yang komprehensif dalam upaya meringkas temuan dan menyimpulkan hasilnya.

\section{Pembahasan}

\section{Pendidikan Agama}

Agama adalah suatu peraturan yang mengatur kehidupan manusia agat tidak menjadi berantakan (kacau) (Wahyuni, 2018: 20). Pembentukan manusia yang baik masyarakat pada umumnya memberikan pendidikan agama kepada anak mereka untuk menjadi manusia yang baik kelak nanti dan menjadi anak yang berbakti kepada mereka itulah harapan orang tua kepada sang anak sehingga dalam penanaman pendidikan perlu peran agama untuk memberikan pendidikan tersebut (Anang, 2019: 103).

Dalam praktek mencari sekolah yang baik dan kualitas yang bermutu orang tua yang mampu untuk menyekolahkan anak mereka di luar kota dengan biaya yang mahal demi untuk mendapatkan pendidikan yang baik bagi anak-anak mereka, dan sebagian mereka menjadi gengsi dimana mereka mempunyai uang yang banyak sementara anak dari kawan-kawan mereka, hal itu menjadi suatu kebanggaan jika kita mampu untuk menyekolahkan anak kita diluar kota dengan menyakini bahwa pendidikan yang diluar kota lebih baik daripada pendidik di dalam daerah sendiri, ini hanya mampu di kalangan menegah keatas sementara dikalangan bawah mereka hanya menyekolahkan anak mereka di dalam daerah seperti pesanteren tradisional yang ada di daerah tersebut. 
Dalam kehidupan pendidikan tidak bisa dilepaskan dari sebuah negera, jika ingin melihat Negara maju dan Negara yang sejahtera berarti pendidikan mereka juga bagus mustahil ada Negara maju tanpa pendidikan yang maju karena kemajuan dibentuk oleh ilmu pengetahuan yaitu pendidikan. Dalam masyarakat juga seperti itu, kalangan masyarakat yang mempunyai ekonomi menengah keatas akan mencari sekolah yang mumpuni untuk anak mereka dengan tujuan untuk mendapatkan pendidikan yang baik, dengan pendidikan pula kita bisa mengangkat derajat bangsa ini di mata dunia (Mundiri, 2016: 59).

Seiring berjalannya waktu, upaya penggabungan antara ilmu umum dan ilmu agama kedalam dunia pendidikan Islam telah dilakukan oleh lembaga-lembaga pendidikan Islam modern, antara lain lembaga pendidikan yang berbasis sekolah Islam terpadu. Dalam sekolah Islam Terpadu (IT) menawarkan sebuah model sekolah alternatif yang berupaya menerapkan pendekatan penyelenggaraan pendidikan yang menggabungkan antara konsep pendidikan agama Islam dengan pendidikan umum, di mana seluruh mata pelajaran berada dalam kemasan ajaran dan norma-norma agama Islam. Dari beberapa pengertian di atas, dapat ditarik kesimpulan bahwa Sekolah Islam Terpadu (IT) merupakan sebuah sekolah yang diselenggarakan dengan memadukan secara integratif ajaran dan nilai-nilai luhur agama Islam dalam struktur kurikulum dengan menggunakan pendekatan pembelajaran efektif dan efisien, yang mengedepankan keseimbangan pencapaian aspek kognitif, afektif, dan psikomotorik melalui pelibatan yang optimal dan kooperatif (koordinatif, konsultatif, sinkronisasi) antara sekolah (terutama guru), keluarga (orang tua), dan masyarakat dalam membangun karakter dan kompetensi yang harus dimiliki peserta didik (Suprapto, 2014: 30).

Tentu langkah demikian ini bisa dikatakan sebagai lompatan besar bagi sistem pendidikan sekolah islam terpadu, sebab ia sudah lagi melakukan dikotomi antara materimateri yang bersifat tauhid (agama) dengan materi yang bersifat umum (sekuler positivistik). Kurikulum demikian ini, jika dilihat dari perspektif epistmologi pendidikan Islam, sebenarnya berasal dari pandangan adanya integrasi ilmu antara ilmu agama dan ilmu umum. Konsep pemahaman keilmuan dalam kurikulum Sekolah Islam Terpadu menunjukkan bahwa ia ingin menjadikan anak didiknyamemiliki penguasaan keilmuan yang integratif yakni bersatunya penguasaanilmu-ilmu yang bersumber dari ayat-ayat tanziliyah yang menghasilkan sainsketuhanan, ayat-ayat dalam diri manusia yang 
menghasilkan sains humanioradan ayat-ayat kauniyah yang menghasilkan sains kealaman.

Konsep pendidikan Sekolah Islam Terpadu berusaha menggabungkan pelbagai latar belakang pendidikan. Sehingga bagi out put sekolah ini diharapkan mampu menguasai keilmuan yang integratif yakni sebuah kesempurnaan penguasaan ilmu-ilmu yang bersumber dari tiga khazanah intelektual Islam, yaitu ayat-ayat tanziliyah yang menghasilkan sains ketuhanan, ayat-ayat dalam diri manusia yang menghasilkan sains humaniora dan ayat-ayat kauniyah yang menghasilkan sains kealaman. Berikut sekema ilmu integrative yang diterapkan pada konsep pendidikan sekolah Islam terpadu, yang mana Gambar A di tengah lingkaran sebagaimana ditunjukkan gambar di bawah ini merepresentasikan anak didik yang memiliki integrasi antara ketiga keilmuan tersebut, sedangkan gambar B merepresentasikan seseorang yang hanya memiliki penguasaan salah satu dari keilmuan tersebut. Hal demikian dapat dilihat dari skema berikut ini (Erwanto, 2019: 71-84).

\section{Branding di Media Sosial}

Konsep Islam Branding di kalangan akademi dan praktisi mendapatkan perhatian yang cukup luas beberapa tahun terakhir ini, konsep ini sangat di minati oleh para masyarakat apalagi ekonomi di kalangan menegah keatas dan menunjukkan populis muslim semakin bertambah (Nasrullah, 2015: 79-87). Sekolah bisa menarik masyarakat jika memiliki Brand (merk), Branding akan menciptakan pikiran yang positif di masyarakat jika brand nya bagus yang diiklankan di dunia maya, anggapan masyarakat jika Brand nya bagus mereka yakin untuk menyekolahkan anaknya di tempat itu dan mendapatkan fasilitas yang baik.

Pola pikir bangsa ini berubah dari pendidikan tradisonal berubah menjadi pendidikan modern di bidang keagamaan dan pendidikan modern inilah yang menjadi Brand untuk memasarkan instansi mereka dengan program-program unggulan seperti hafizh al-Qur'an, daurah, program bahasa, birrul walidain, go to school, dll. Modernisasi pendidikan ini di sambut hangat masyarakat muslim di Indonesia mereka berbondong-bondong datang untuk mendaftar dari daerah yang jauh bahkan dari luar sumatera, yaitu jawa dan nusa tenggara barat. 
Brand yang di iklankan dari media sosial dengan program ungulan sperti tahfihz 30 juz dan daurah dan karantina menjadi menjadi acuan pertama dari kalangan masyarakat untuk bisa sekolah di instasi tersebut. Mereka datang jauh jauh harapan orang mereka nanti dan orang tua mereka bisa hafal a-Qur'an 30 juz. Di lain sisi Brand yang di tawarkan adalah tempat yang bagus gedung yang unik. Tempat bangunan sekolah ini sangat indah dan unik karena di kelilingi tebing-tebing yang tinggi dan air terjun yang tinggi dan khas bangunan adalah bangunan Ala Eropa. Dan ini menjadi nilai jual yang sangat tinggi di kalangan masyarakat. Lembaga pendidikan Islam melakukan perubahan dari Sistem pendidikan di Indonesia atas perkembangan daan tuntutan zaman. Di sebabkan ketertinggalan sistem pendidikan muslim yang jauh tertinggal dari kemajuaan Barat, Modernisasi ini adalah gerekan pembaruan Islam (Mundiri, 2016: 59).

Brand kelembagaan yang di bangun juga merambah ke manajemen yang mudah, sistem manajemen yang ditawarkan adalah sistem manual dan online, orang tua tidak perlu repot-repot untuk membayarkan uang sekolah manual tetapi sudah online sehingga memudahkan bagi orang tua cukup dengan transper sekalian dengan uang jajan siswa cukup di transper, jika siswa perlu untuk jajan cukup pergi kekantin dengan di lengkapi dengan PIN masing-masing. Siswa tidak boleh memegang uang langsung, memegang uang dengan langsung adalah pelanggaran, Dengan sistem seperti ini di kalangan siswa tidak ada kehilangan uang dan pencurian dan menjadi sebuah sistem yang bagus selama ini di kalangan pendidikan tradisional banyak kehilangan dan pencurian.

\section{Praktek Tahfizh}

Pendidikan Islam yang lagi trend saat ini adalah menghafal a-Qur'an, antusias masyarakat itu membuktikan kemajuan Islam pada saat ini (Hidayah, 2016: 63). Misalnya banyak sekali sekolah tahfizh yang bermunculaan dengan tawaran anaknya akan hafal alQur'an jika sekolah di situ. Tahfizh al-Qur'an juga menjadi ekstrakulikuler di tingkat SD, SMP maupun SMA bahkan sudah ada yang menjadi kurikulum di sekolah tersebut baik negeri atau swasta. Menghafal Al-Qur'an yang di sebut juga dengan tahfizh al-Qur'an adalah mengahafal teks tertulis yang ada di kita suci yang belum sama sekali di hafal, menghafal Al-Qur'an adalah perbuatan yang terpuji dan mulia bagi mereka yang mau menghafalnya (Khusniyah, 2014: 52). 
Cara untuk Menjaga al-Qur'an adalah dengan mengahafalnya, sebagai bentuk apresiasi dan al-Qur'an adalah satu-satunya kita suci yang di hafal teks diluar kepala mulai zaman dahulu hingga sekarang (Fachruddin, 2017:326). Al-Qur'an berisi sebanyak 30 juz dan 600 halaman. Allah memudahkan bagi orang yang menghafalnya sesuai dengan Janji Allah dalam surah al-Qamar ayat 17: Dan Sesungguhnya telah Kami mudahkan Al-Quran untuk pelajaran, Maka Adakah orang yang mengambil pelajaran (Al-Qamar: 17). Jaminan untuk kemudahan untuk menghafal al-Qur'an walaupun jumlah yang banyak tetapi bisa lengket di otak dan garansi Allah bahwa ayat-ayat al-qur'an ini terjaga oleh para huffazh (Penghafal al-Qur'an). Pada dasarnya penjagaan al-Qur'an dan pelestariannya sudah di mulai dari sejak zaman Nabi yaitu al-Qur'an diturunkan (Sakho, tt: 3). Penghafalan al-Qur'an sama dengan menjaga otensitas dan orisinalitas al-Qur'an itu sendiri dan menjadi pahala bagi yang menghafalnya.

\section{Kesimpulan}

Modernisasi pendidikan adalah salah satu kemajuan pendidikan Islam di Indonesia, modernisasi ini menawarkan Branding yang berbeda dengan pendidikan yang tradisional. Branding yang di tawarkan adalah tahfizh al-Qur'an, Birrul Walidaian dan program bahasa menjadi nilai yang unggul di kalangan masyarakat yang di promosikan melalui media sosial (facebook). Ketidakmampuan pendidikan tradisional untuk mengemas pendidikan yang baru, bagi kalangan menengah keatas lebih percaya kepada sekolah yang modern daripada tradisonal karena kemampuan sekolah modern dengan branding tempat dan managment yang baik.

\section{Daftar Rujukan}

Al Anang, A. (2019). Sejarah Perkembangan Ilmu Pengetahuan dalam Islam. Fajar Historia: Jurnal Ilmu Sejarah dan Pendidikan, 3(2), 98-108.

Erwanto, E. (2019). Penerapan Kurikulum Jaringan Sekolah Islam Terpadu (JSIT) Dalam Pembentukan Karakter Religius Siswa SMPIT Khoiru Ummah Rejang Lebong. Al-Bahtsu: Jurnal Penelitian Pendidikan Islam, 4(1).

Fachrudin, Y. (2017). Pembinaan Tahfizh Al-Quran di Pesantren Tahfizh Daarul Qur'an Tangerang. Kordinat: Jurnal Komunikasi antar Perguruan Tinggi Agama Islam, 16(2), 325-348.

Hariyati, Farida, and Dini Wahdiyati. (2019.) "Penguatan Dakwah Virtual sebagai Upaya Memakmurkan Masjid Berbasis kegiatan Remaja Masjid." Jurnal Solma 8(2), 239-247. 
Hidayah, N. (2016). Strategi Pembelajaran Tahfidz Al-Qur'an di Lembaga Pendidikan. Ta'allum: Jurnal Pendidikan Islam, 4(1), 63-81.

Isa, Abdul Qodir. (2005). Hakekat Tasawuf, Penerjemah Khairul Harahap dan Afrizal Lubis, Jakarta: Qisthi Press.

Khusniyah, Anisa Ida. (2014). Menghafal Al-Qur'an Dengan Metode Muraja'ah Studi Kasus Di Rumah Tahfidz Al-Ikhlash Karangrejo Tulungagung, Skripsi. Tulungagung: Fakultas Tarbiyah IAIN Tulungagung.

Lukmana, Lukmana (2019) Strategi Pengelolaan Media Sosial dalam Pengembangan Dakwah di Majelis Taklim Dzikir dan Sholawat As-Shofa Banjarmasin. Skripsi. Banjarmasin: Fakultas Dakwah dan Ilmu Komunikasi UIN Antasari.

Multazam, Ahmad. 2013. Pendekatan Sejarah dalam Memahami Agama. https://multazam-einstein.blogspot.co.id/2013/12/pendekatan-sejarah-dalammemahami-agama.html. Diakses tanggal 6 November 2020.

Mundiri, A. (2016). Strategi Lembaga Pendidikan Islam dalam Membangun Branding Image. Pedagogik: Jurnal Pendidikan, 3(2).

Mundiri, A. (2016). Strategi Lembaga Pendidikan Islam Dalam Membangun Branding Image. Pedagogik: Jurnal Pendidikan, 3(2).

Nasrullah, M. (2015). Islamic Branding, Religiusitas dan Keputusan Konsumen Terhadap Produk. Jurnal Hukum Islam, 13(2), 79-87.

Sakho, Muhammad Ahsin. t.t. Kiat-Kiat Menghafal Al-Qur'an. Bandung: Badan Koordinasi TKQTPQ-TQA.

Sugiyono. (2014). Metode Penelitian Pendidikan Pendekatan Kuantitatif, Kualitatif, dan $R \& D$. Bandung: Alfabeta.

Suprapto, S. (2014). Model Pembelajaran Pendidikan Agama Islam Terpadu di Sma-It Darul Hikam Bandung. EDUKASI: Jurnal Penelitian Pendidikan Agama dan Keagamaan, 12(1).

Suyatno, 2013. Sekolah Islam Terpadu; Filsafat, Ideologi, dan Tren Baru Pendidikan Islam di Indonesia. Jurnal Pendidikan Islam 2(2), 355-377.

Wahyuni, (2018). Agama \& pembentukan Struktur Sosial Pertautan Agama, Budaya, dan Tradisi Sosial, Jakarta: Prendamedia.

Zeid, Mestika. (2014). Metode Penelitian Kepustakaan. Jakarta: Yayasan Pustaka Obor Indonesia. 